DOI

\title{
АДАПТАЦІЯ МЕТОДИЧНИХ МАТЕРІАЛІВ ДО ПРАКТИЧНОГО ЗАНЯТТЯ НА ТЕМУ “ПРОВЕДЕННЯ УРОКУ ЗДОРОВ’Я” НА III КУРСІ СТОМАТОЛОГІЧНОГО ФАКУЛЬТЕТУ ДЛЯ ПІДВИЩЕННЯ ЙОГО ПРАКТИЧНОГО СПРЯМУВАННЯ
}

\author{
Г. М. Мельничук, І. Р. Костюк, Н. І. Шовкова, О. В. Базалицька, А. Д. Бабенко, \\ М. В. Білищук, О. Ю. Потяк, О. Є. Кошкін, О. І. Яворська, В. В. Аваков \\ ДВНЗ “Івано-Франківський національний медичний університет”
}

\section{ADAPTATION OF METHODICAL MATERIALS FOR PRACTICAL CLASS “HAELTH LESSON" AT THE III COURSE OF THE STOMATOLOGICAL FACULTY REGARDING THE IMPROVEMENT OF ITS PRACTICAL FOCUS}

\author{
H. M. Melnychuk, I. R. Kostyuk, N. I. Shovkova, O. V. Bazalytska, A. D. Babenko, \\ M. V. Bilyshchuk, O. Yu. Potyak, O. Ye. Koshkin, O. I. Yavorska, V. V. Avakov \\ SHEI "Ivano-Frankivsk National Medical University"
}

\begin{abstract}
Кредитно-модульна система освіти має свої переваги, але є практичні заняття, на яких необхідно відступити від деяких її принципів. На III курсі стоматологічного факультету при вивченні предмета "Профілактика стоматологічних захворювань” згідно з робочою програмою є практичне заняття № 17-18 на тему “Проведення уроку здоров’я”, на яке відводиться чотири академічні години. Це заняття передбачає роботу студентів в організованих дитячих колективах. Із метою повного його практичного спрямування на кафедрі дитячої стоматології Івано-Франківського національного медичного університету внесено зміни в “Розділ VI. План і організаційна структура заняття" до цієї методичної розробки, що полягають у проведенні генеральної репетиції уроку здоров’я замість опитування і тестування, а основна частина заняття відводиться на власне виступ - урок здоров'я. При цьому вихідний та кінцевий рівень знань студентів викладач з'ясовує на попередньому занятті. Проведена нами адаптація методичних матеріалів допомагає отримати повне практичне спрямування цього практичного заняття та дозволяє студентам і викладачу цілком віддатися творчій праці.
\end{abstract}

There are advantages of the transfer-module system, but at practical lessons some principles might be skipped. According to the program of "Prophylaxis of stomatological disorders" at the III course of stomatological faculty the subject of the practical lesson № 17-18 is a conduction of the "Health lesson" that should be managed within four academic hours. This practical lesson should be held in the organized children's groups. To enhance its practical guide we have to introduce some changes to the "Part VI. Plan and management of the lesson” at the Pediatric Stomatology Department of Ivano-Frankivsk National Medical University. The dress rehearsal is operated before the lesson instead of the test control and oral part and the main part is a performance itself. Besides, the initial and the final level of the test control should be administered at the previous lesson. Therefore, such innovation of methodical materials meets all practical requirements and provides the students and pedagogues with massive options of creativity.

Вступ. Модернізація національної системи вищої освіти - це цілеспрямований рух до євроінтеграції українського суспільства шляхом розвитку сучасного механізму освітньої діяльності. В Україні запроваджено кредитно-модульну систему організації навчального процесу, яка сприяє підвищенню можливостей студентської мобільності, досягненню сумісності програм підготовки та кваліфікацій, забезпеченню навчання студентів за індивідуальною варіативною системою освітньо-професійних програм, підвищенню якості підготовки фахівців та їх конкурентоспроможності, забезпеченню до-

(c) Г. М. Мельничук, I. Р. Костюк, Н. І. Шовкова та ін. ступу до ринків праці, а також - посиленню престижу вищої освіти [1].

Для забезпечення реалізації мети - спрямування України до європейського рівня вищої освіти необхідним елементом є оволодіння знаннями про особливості сучасної світової освітньої парадигми, яка полягає у поєднанні, узгодженні та взаємному доповненні репродуктивно-консервативної та прогресивно-гуманістичної парадигм в єдиному освітньому просторі. Визначальними тенденціями та базовими домінантами сучасної освіти є ї ціннісна й особистісна орієнтованість [5].

При цьому перед викладачами та студентами вищих навчальних закладів постає нове завдання - 
інтеграція в європейську модель освіти 3 активним застосуванням новітніх інформаційнокомунікаційних та аудіовізуальних технологій, але зі збереженням власних традицій [2].

Основна частина. Безперечно, кредитномодульна система освіти має свої переваги, але є практичні заняття, на яких необхідно відступити від деяких її принципів зокрема від стандартної схеми їх проведення, яка включає визначення вихідного рівня знань за допомогою тестів та контрольних питань для оцінки вихідного рівня, основної частини заняття для відпрацювання практичних навичок та заключної частини, що знову ж таки передбачає використання тестів для визначення кінцевого рівня знань.

Зокрема, на III курсі стоматологічного факультету при вивченні предмета “Профілактика стоматологічних захворювань” згідно з робочою програмою передбачено практичне заняття на тему “Проведення уроку здоров’я”, на яке відводиться чотири академічні години. Таке заняття має чисто практичне спрямування, оскільки передбачає роботу студентів в організованому дитячому колективі з дітьми різних вікових груп. Це - практична навичка, що має на меті навчити студента вміння спілкуватися з дитиною, донести до неї отримані на попередніх заняттях знання з профілактики стоматологічних захворювань. Урок здоров’ я за своєю суттю є активною формою санітарно-просвітницької роботи, яка включає: бесіди, роз’яснення, лекції, диспути, презентації, конференції, а для дітей молодшого віку - їі найцікавішу форму - театралізоване дійство, виставу чи виступ у вигляді тематичної казки.

На нашу думку, театралізоване подання інформації - найефективніший метод активної форми санітарно-просвітницької роботи. Таким чином відбувається ненав’язливе навчання дітей у формі гри. Основи гігієнічної культури подаються дітям як цікаві казкові вистави, де акторами є студенти. Зі сцени улюблені мультиплікаційні та літературні герої розповідають глядачам про те, що треба робити, щоб зуби були здоровими, а усмішка - завжди красивою. Отримані знання та навички закріплюються іграми, конкурсами та вікторинами, а також за допомогою таких засобів, як санбюлетні, плакати, стенди, пам’ятки, закладки, кросворди, тематичні іграшки та інші унаочнення [3, 4].

Традиційно практичне заняття “Проведення уроку здоров’я” проводиться за межами вузу на території дитячих навчальних закладів -дитячих садків, загальноосвітніх шкіл чи шкіл-інтернатів.
Організаційні моменти щодо згоди керівництва цих закладів на проведення такого заняття бере на себе викладач.

Із метою більш повного практичного спрямування цього практичного заняття викладачами кафедри дитячої стоматології Івано-Франківського національного медичного університету перероблено та доповнено методичні матеріали. Зокрема, у методичну розробку для викладачів до проведення практичного заняття № 17-18 із профілактики стоматологічних захворювань внесено зміни в “Розділ VI. План і організаційна структура заняття”, а саме: під час першого підготовчого етапу заняття не здійснюється традиційне опитування та тестування для 3’ясування вихідного рівня знань, а замість цього проводиться генеральна репетиція казкової вистави для молодших дітей чи виступу-презентації для дітей старших класів із використанням таких матеріалів методичного забезпечення, як сценарій та реквізити для виступу. При цьому вихідний та кінцевий рівень знань студентів викладач з'ясовує на попередньому занятті на тему “Гігієнічне стоматологічне навчання та виховання дітей в організованих дитячих колективах”, що за своєю суттю $є$ теоретичною частиною заняття з наступної теми “Проведення уроку здоров’я”.

Другий основний етап заняття включає формування професійних вмінь і навичок, а саме: складання плану навчально-гігієнічних заходів в організованому дитячому колективі залежно від вікової групи; складання сценарію казки чи презентації виступу; оволодіння методиками чищення зубів; проведення бесіди про користь збалансованого та раціонального харчування для здоров'я зубів; демонстрація методів застосування основних та додаткових засобів гігієни. Матеріали методичного забезпечення цього етапу заняття - це сценарій виступу (казкової вистави), презентація, муляжі основних та додаткових засобів гігієни, санбюлетні, плакати, закладки, картинки, кросворди, брошури, відеоматеріали, фотоматеріали, аудіоматеріали, реквізит для проведення театралізованого дійства (казки), тематичні іграшки.

На заключному етапі заняття, функцією та змістом якого є контроль і корекція рівня професійних вмінь та практичних навичок, здійснюється індивідуальний контроль теоретичних знань та їх практичної реалізації. При підведенні підсумків заняття оцінюється не лише теоретична та практична складова, але й організаційна.

Отже, в кінці практичного заняття “Проведення уроку здоров’я” буде виставлено дві оцінки в ба- 
лах (максимально - 4 бали, мінімально - 2 бали). У першій графівиставляється оцінка за організаційну діяльність та активну участь у проведенні цього практичного заняття. Зазвичай за це всім студентам ставиться найвищий бал, за винятком тих, які взагалі не брали ніякої участі в ньому, або були байдужими (як правило, таких студентів немає). У другій графі ставиться комплексна оцінка за теоретичну підготовку та оволодіння практичною навичкою (проведення тематичних бесід, вміння спілкуватися $з$ дітьми тощо), яку виявляє викладач, спостерігаючи за роботою студентської групи в організованому дитячому колективі.

\section{Список літератури}

1. Бабецька I. Я. Особливості підготовки студентів в умовах кредитно-модульної системи організації навчального процесу та напрями вдосконалення / I. Я. Бабецька, I. О. Турчак // Досвід впровадження кредитно-модульної системи організації навчального процесу у вищих навчальних закладах Прикарпаття III-IV рівнів акредитації: тези доп. наук.-метод. конф., 29 квітня 2015 р.- ІваноФранківськ, 2015. - С. 15-16.

2. Застосування активних методів навчання для формування продуктивної творчої діяльності студентів на кафедрах дитячої стоматології / М. В. Білищук, Н. І. Кольцова, Р. В. Казакова, Ю. Ю. Переста // Новини стоматології. - 2011. - № 4 (69). - С. 88-90.

3. Методика проведення практичних занять 3 профілактики стоматологічних захворювань у формі “Уроків
Висновки: 1. Проведена нами адаптація методичних матеріалів до практичного заняття “Проведення уроку здоров' я” у світлі вимог кредитномодульної системи освіти допомагає отримати повне практичне спрямування цього заняття та дозволяє студентам і викладачу цілком віддатися творчій праці.

2. Творча робота студентів і викладача допомагає сформувати у дітей, навіть раннього віку, систему стійких навичок щодо дотримання гігієни ротової порожнини та, найголовніше, - зняти психологічний бар’єр між “страшним” лікарем-стоматологом та маленьким пацієнтом.

здоров’я” / М. А. Лучинський, М. Н. Воляк, І. Р. Костюк та ін. // Свідоцтво на раціоналізаторську пропозицію від 25 січня 2007 року № 4/2543.

4. Методика проведення активної форми санітарнопросвітницької роботи у вигляді стоматологічних конференцій “Студенти-дітям” / М. А. Лучинський, М. Н. Воляк, І. Р. Костюк та ін. // Свідоцтво на раціоналізаторську пропозицію від 25 січня 2007 року № 2/2542.

5. Савченко О. О. Західна парадигма освіти на початку XXI століття (соціально-філософський аналіз) : дис. ... канд. філософ. наук: спец. 09.00.03 [Електронний ресурс] / О. О. Савченко. - 2008. - Режим доступу : http:// disser.com.ua/content/344152.html 1.

Отримано 12.10 .15 